\title{
Metamaterial-inspired Near-field Resonant Parasitic Structure for Directional Suppression of Narrow-band EMI/RFI in Compact Systems
}

\author{
Ruaro, Andrea; Thaysen, Jesper; Jakobsen, Kaj Bjarne
}

Link to article, DOI:

10.1109/USNC-URSI.2013.6715424

Publication date:

2013

Link back to DTU Orbit

Citation (APA):

Ruaro, A., Thaysen, J., \& Jakobsen, K. B. (2013). Metamaterial-inspired Near-field Resonant Parasitic Structure for Directional Suppression of Narrow-band EMI/RFI in Compact Systems. Abstract from 2013 IEEE AP-

S/USNC-URSI Symposium, Orlando, Florida, United States. https://doi.org/10.1109/USNC-URSI.2013.6715424

\section{General rights}

Copyright and moral rights for the publications made accessible in the public portal are retained by the authors and/or other copyright owners and it is a condition of accessing publications that users recognise and abide by the legal requirements associated with these rights.

- Users may download and print one copy of any publication from the public portal for the purpose of private study or research.

- You may not further distribute the material or use it for any profit-making activity or commercial gain

- You may freely distribute the URL identifying the publication in the public portal

If you believe that this document breaches copyright please contact us providing details, and we will remove access to the work immediately and investigate your claim 


\section{Metamaterial-inspired Near-field Resonant Parasitic Structure for Directional Suppression of Narrow-band EMI/RFI in Compact Systems}

Andrea Ruaro*1,2, Jesper Thaysen ${ }^{2}$, and Kaj B. Jakobsen ${ }^{1}$

${ }^{1}$ DTU Elektro, Technical University of Denmark, DK-2800 Lyngby

${ }^{2}$ GN ReSound A/S, Lautrupbjerg 7, DK-2750 Ballerup, Denmark

This paper describes the application of an electrically small, metamaterialinspired, near-field resonant parasitic (NFRP) element in a nearly space-less design for suppression of narrowband radio-frequency interference (RFI) and its higher-order harmonics. The design of the NFRP structure is inspired by results presented in the existing literature. The possibility of using it as a notch filter as a design integrated in a Printed Circuit Board (PCB) and its advantages over known solutions like electromagnetic bandgap (EBG) or defected ground (DGS) structures are discussed; the results for different orientations are shown. The coupling mechanism of the structure to transmission lines is briefly presented.

To comply with the EMC regulations worldwide is of utmost importance for the diffusion of electronic products. Designers are nowadays facing new issues due to factors like increased clock speed, coexistence of audio and analogue systems, shrinking of PCB dimensions, etc. In most cases, especially for devices where the space is critical as are hand-held terminals or medical implants, there is no room to apply traditional solutions as proper grounding, filtering, and shielding. Furthermore, there is an interest to attenuate a single frequency and its higher-order harmonics: a problem arises when a transmission line needs filtering for a frequency that is very close to the operating frequency.

The filtering effect is here achieved due to the resonant behavior of the NFRP element. The results are obtained by the use of FEM-based simulations. The design of the NFRP element is based on the existing literature, and in particular on the work of Ziolkowski et al. The structure is implemented directly in the substrate, in a layer between the signal tracks and the ground (or power) layer. Two orientations of the structure are analyzed, and the importance of the directionality in complex environments is highlighted. An electric-coupled electric-inspired element is shown here and is able to provide narrowband attenuation of a signal travelling on a microstrip line of more than $10 \mathrm{~dB}$ for one orientation, while it is $2 \mathrm{~dB}$ only when the structure is rotated by $90^{\circ}$.
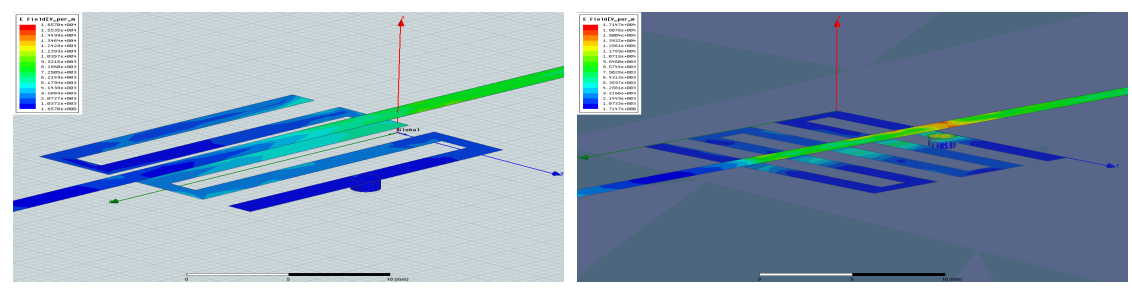